\title{
Comparative Analysis of Two Bioplasticizers Used to Modulate the Properties of PLA Biocomposites
}

\author{
MARIA RAPA ${ }^{1}$, RALUCA NICOLETA DARIE NITA2 ${ }^{2}$ ANAMARIA IRIMIA2 ${ }^{2}$ MORTEN SIVERTSVIK ${ }^{3}$, J AN THOMAS ROSNES ${ }^{3}$, \\ ANCUTA ROXANA TRIFOI ${ }^{1}$, CORNELIA VASILE ${ }^{2}$, ELISABETA ELENA TANASE ${ }^{4}$, TIMEA GHERMAN ${ }^{1}$, MONA ELENA POPA ${ }^{4}$, \\ AMALIA CARMEN MITELUT ${ }^{4 *}$ \\ ${ }^{1}$ CPAO S.A., 8 Carpati Str., 551022, Medias, Sibiu, Romania \\ 2Petru Poni Institute of Macromolecular Chemistry, 41 Grigore Ghica Voda Alley, 700487, Iasi, Romania \\ ${ }^{3}$ Nofima AS, Richard Johnsens gt 4, 4068 Stavanger, Norway \\ ${ }^{4}$ University of Agronomic Sciences and Veterinary Medicine Bucharest, 59 Marasti Blvd.,011464, Bucharest, Romania
}

\begin{abstract}
The present paper deals with a comparative study on the influence of two different bioplasticizers: acetyl tributylcitrate (ATBC) and LAPOL108 on the mechanical and antimicrobial properties of poly(lactic acid) PLA containing 1 wt.\% chitosan. PLA based biocomposites were investigated by means of processing behavior, FT-IR spectroscopy, DSC analysis, tensile and barrier properties, migration in food simulants and antifungal activity. Based on the obtained results it can appreciated that the properties of the PLA based biocomposites could be appropriate for designing flexible or rigid food packaging depending of the bioplasticizer used.
\end{abstract}

Keywords:polylactic acid, bioplasticizer, chitosan, melt processing, food packaging

Currently, food packaging market is in a continuous growth in order to meet the demands of the consumers. Most food packaging materials are obtained from conventional polymers, such as polyethylene, polyethylene terephthalate, polypropylene, polystyrene. Although these conventional polymers are conforming to national and international regulations, the packaging materials represent a huge problem because of large quantity of accumulated packaging waste, the lack of biodegradability and the long persistence in the environment. In this context, the materials used for food packaging must be environmentfriendly. At the same time, in order to ensure full quality of food, numerous efforts are made in order to develop specific packaging materials that present simultaneously mechanical, thermal, optical, barrier and antibacterial adequate properties [1,2]. The physical characteristics of the polymers for packaging depend on their chemical structure, molecular weight, crystallinity and processing conditions. Packaging materials must be tough enough and flexible to ensure their handling, in addition they must ensure the tightness of the pack. Also, when the polymer composites come in contact with food, there is a possibility that some chemicals to migrate to food simulants, this phenomenon being unacceptable from food safety legislation point of view.

Polylactic acid (PLA) has received special attention in recent decades as one of the most attractive packaging materials due to its biodegradability, and lack of ecotoxicity and biocompatibility [3]. PLA can be used for making thermoformed rigid packaging, films for covering the trays and bottles. Also PLA materials show good transparency and mechanical properties, but they are considered inappropriate for food packaging applications due to the low flexibility, low melt viscosity, bad gas barrier properties, relative low heat distortion temperature and slow crystallization rate $[4,5]$. As consequence the mechanical properties of PLA based materials should be improved.

There are known different techniques for making polylactic acid flexible, such as: addition of a plasticizer, copolymerization or blending with flexible polymers [6]. A large number of papers related the use of various plasticizers for improve the ductility of PLA-based material: polyethylene glycol (PEG) [7], Lapol 108 [8], citrates [9], etc. For food packaging applications, the plasticizers must to be compatible with PLA matrix [6], with a relatively low molecular weight to produce the desired mechanical properties, biodegradable and no volatile compounds to be release to packed food. Also the amount of plasticizer added into PLA matrix must be optimal in order to avoid the phase separation. In our previously papers, bis[2-(2butoxyethoxy)ethyl] adipate and tributyl orto-acetyl citrate up to $20 \mathrm{wt}$ \% in content have been considered the best plasticizers for the significantly improvement of the PLA processability and flexibility [10], since the incorporation of PLA oligomer, L-lactide, poly(ethylene glycol), and epoxidized soybean oil have improved the melt flow and processability, increasing the hydrophilicity of the resulted plasticized PLA systems [11].

Also, by the incorporation of some natural polymers into PLA matrix, the high crystallinity in PLA with a positive effect on the mechanical properties as well as the service temperature is obtained [12]. Chitosan is the commonly used name for poly-[1,4]-[3-D-glucosamine]. It is the second most abundant polysaccharide found in nature after cellulose and its films have great potential to be used as packaging material due to the antimicrobial activity, nontoxicity and biodegradability [13, 14]. Several studies have reported the antimicrobial films based on poly(ethylene) or poly(vinyl alcohol) containing chitosan obtained by coating [15] or melt processing [16, 17]. Poly(lactic acid) (PLA) biocomposites containing chitosan in amount up to $5 \mathrm{wt} . \%$ and tributyl 0 -acetyl citrate (ATBC) were obtained and studied both in respect with the changes in mechanical properties and antifungal/antimicrobial activities [18]. It has been established that the amount of chitosan of $1 \mathrm{wt} . \%$ into PLA biocomposites led to a significant reduction in S. aureus and E. colion the contact surfaces.

\footnotetext{
*email: amaliamitelut@yahoo.com; Phone:+40745769453
} 
The aim of this study was to evaluate the influence of two different bioplasticizers, namely: acetyl tributylcitrate (ATBC) and LAPOL108 on the mechanical, thermal and antifungal properties of PLA based biocomposites containing $1 \%$ chitosan.

\section{Experimental part}

\section{Materials}

Poly(lactic acid) (PLA) Ingeo ${ }^{\text {TM }}$ biopolymer 2003D was provided by NatureWorks LLC (Minnetonka, MN, USA) and used as polymeric matrix. It is accepted by the Food \& Drug Administration (FDA) to be used in food packaging. PLA was obtained from renewable annual resources and is characterized by a content of D-lactide of $4 \%$, a density of $1.24 \mathrm{~g} / \mathrm{cm}^{3}$ and a melt flow index (MFI) of $5-7 \mathrm{~g} / 10 \mathrm{~min}$ (at $210^{\circ} \mathrm{C} / 2.16 \mathrm{~kg}$ ).

As bioplasticizers, tributyl o-acetyl citrate (ATBC) (molecular weight of $406 \mathrm{~g} / \mathrm{mol}$, density at $25^{\circ} \mathrm{C}$ of 1.055 $\mathrm{kg} / \mathrm{L}$ and assay (GC) $99.35 \%$ ) supplied by Proviron, Belgium and LAPOL 108 (masterbatch containing 70\% PLA) (LAPOL, LLC, USA) were used.

Medium molecular weight chitosan (CS), with a degree of deacetylation of $75 \%$ and a viscosity of $208 \mathrm{cps}$ ( $c=1 \%$ at $1 \%$ acetic acid) was purchased from SIGMA-ALDRICH.

The tested microoganisms (Aspergillus brasiliensisATCC 16404, Fusarium graminearum G87 and Penicillium corylophilum CBMF1) were provided by the Faculty of Biotechnology from USAMVB.

\section{Preparation of blends and composites}

Melt blending of PLA with ATBC and LAPOL 108 respectively, and $1 \mathrm{wt} \%$ CS was carried out in a Brabender Plastograph at a temperature of $170{ }^{\circ} \mathrm{C}$ and rotor speed of $60 \mathrm{rpm}$ for $6 \mathrm{~min}$. The content of each bioplasticizer was set at $20 \mathrm{wt}$ \% with respect to PLA. Before mixing, the PLA and LAPOL 108 were oven dried at $60^{\circ} \mathrm{C}$ in a vacuum oven overnight. The chitosan was dried at $110^{\circ} \mathrm{C}$ for $24 \mathrm{~h}$ before use. The ATBC was mixed with CS before being loaded into the Brabender Plastograph and then it was mixed with melted PLA. In the second case, both PLA and LAPOL 108, as pellets shapes, were melt mixed in a Brabender Plastograph then the CS was added into the melted mixture. The sheets with $(200 \times 200 \times 1) \mathrm{mm}$ sizes and films with thickness of max. $200 \mu \mathrm{m}$ were obtained from the prepared melted products using the compression moulding, at a temperature of $175^{\circ} \mathrm{C}$ and $125 \mathrm{~atm} / 150 \mathrm{~atm}$ pressure, for pressing time of $5 \mathrm{~min} / 3 \mathrm{~min}$ (for sheets/films). A neat PLA sample was prepared in the same conditions and was considered as a reference. The specimens for tests were prepared from these sheets/films.

\section{Investigation methods}

Melt processability. The processing behavior of the prepared samples was evaluated according to the method described in [18].

\section{Fourier transform infrared (FT-IR) spectroscopy studies}

The obtained films were analyzed by Fourier Transform Infrared Spectroscopy in Attenuated Total Reflectance mode (FTIR - ATR) using a ZnSe crystal with an incidence angle of $45^{\circ}$. All spectra represent the average of 20 scans recorded at $4 \mathrm{~cm}^{-1}$ resolution in a range of $4000-750 \mathrm{~cm}^{-1}$, using air as background.

\section{Differential scanning calorimetry (DSC) measurements}

Thermal analysis of materials was carried out on a DSC analyzer (823e Mettler Toledo). Small amounts (circa $5 \mathrm{mg}$ ) of dry samples were placed into aluminum pans, sealed and first heated between 35 and $175^{\circ} \mathrm{C}$ ata scanning speed of $5^{\circ} \mathrm{C} / \mathrm{min}$. An empty aluminum pan was used as reference. The glass transition temperatures $\left(\mathrm{T}_{\mathrm{m}}\right)$, cold crystallization temperature $\left(T_{c}\right)$, melting temperature $\left(T_{m}\right)$ and corresponded enthalpy $\left(\Delta \mathrm{H}_{\mathrm{c}}\right.$ and $\left.\Delta \mathrm{H}_{\mathrm{m}}\right)$ were obtained from DSC thermograms. The PLA crystallinity degree $\left(X_{c}\right)$ was calculated using the following

$$
X_{c, P L A}=\frac{\Delta H_{m}}{\Delta H_{m}^{0} \cdot w t . \%} \cdot 100, \%
$$

where: $\Delta H_{m}$ is the melting enthalpy of the specimens (J/ g); $\Delta \mathrm{H}^{0}$ is the enthalpy value for a theoretically $100 \%$ crystalline PLA $\left(93.1 \mathrm{~J} \mathrm{~g}^{-1}\right)$. The weight fractions of PLA and of PLA from LAPOL 108 masterbatch from each sample were used for $X_{c}$ calculation.

\section{Mechanical properties}

Tensile strength, elongation at break and Young's modulus were determined according to the procedure described in [18].

\section{Barrier properties}

Water vapor transmission rate (WVTR) of the samples was determined according to [18]. The oxygen transmission rate (OTR) test were conducted with a PERME ${ }^{\mathrm{TM}}$ OX2/231 Permeability Tester from Labthink Instruments CO., LTD (Jinan, China), at RH $\sim 50 \%$ and a temperature of $23^{\circ} \mathrm{C}$. The oxygen flow rate was fixed at 20

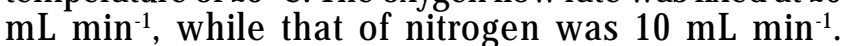
Specimens with $(108 \times 108 \times 0.2) \mathrm{mm}$ dimensions were used for barrier tests.

\section{Overall migration test}

Food simulants: $3 \%$ acetic acid, $10 \%$ or $50 \%$ ethanol and alternative simulants as organic solvents (usually isooctan) are used for fatty food packaging. The amount of transferred substances to the food should not exceed $60 \mathrm{mg} \mathrm{kg}^{-1}$ food or $10 \mathrm{mg} \mathrm{dm}^{-2}$ based on surface area [19]. Overall migration for the PLA-based composites was tested using two simulants: $3 \%$ acetic acid (w/v) (simulant B) (recommended for acidic food) and $50 \%$ ethanol (v/v) (simulant D1) for 10 days at $40^{\circ} \mathrm{C}$ (recommended for aqueous, alcoholic and milky food, according to EN 1186 Part 5 (standard cell, one-sided migration). Four circular specimens of $0.2 \mathrm{~mm}$ thickness with an area of $2.11 \mathrm{dm}^{2}$ were used for each simulant.

\section{Antifungal properties}

The evaluation of the antifungal activity was realized by testing the films (thickness of $0.2 \mathrm{~mm}$ ) against three food degradation fungi: Aspergillus brasiliensis ATCC 16404, Penicillium corylophilum CBMF1 and Fusarium graminearum $\mathrm{G} 87$ at the contact surface, according to the method reported in [18]. The concentration of spore suspensions inoculum was of $10^{6} \mathrm{spores} / \mathrm{mL}$.

\section{REsults and discussions \\ Processing behaviour}

The processing behavior of the obtained blends was evaluated from the following characteristics: torque at different processing times and at the end of mixing and the melt visc osity of samples (s), calculated by dividing the torque recorded at the end of mixing to the rotor speed ( 60 $\mathrm{rpm}$ ). Mixing torques ( $T Q$ ) at different times ( $1 \mathrm{~min}, 5 \mathrm{~min}$ ) and steps of processing (maxim torque and end of torque) and melt viscosity $(s)$ of neat PLA, plasticized PLA and PLA-biocomposites are summarized in table 1.

Due to its semicrystalline structure, PLA shows the highest melt viscosity $\left(0.56 \mathrm{~N} \mathrm{~m} \mathrm{rpm}^{-1}\right)$ and a decreased value of torque up to the end of melt processing in 


\begin{tabular}{|c|c|c|c|c|c|c|}
\hline Sample & $\begin{array}{l}\text { TQlmin } \\
(\mathrm{N} \mathrm{m})\end{array}$ & $\begin{array}{l}T_{\max } \\
(\mathrm{N} \mathrm{m})\end{array}$ & $\begin{array}{l}\text { TQ } \min \\
(\mathrm{Nm})\end{array}$ & $\begin{array}{l}T_{\text {fin }} \\
(\mathrm{N} \mathrm{m})\end{array}$ & $\begin{array}{c}\mathrm{\eta} \\
\left(\mathrm{N} \mathrm{m} \mathrm{rpm}^{-1}\right)\end{array}$ & Table 1 \\
\hline PLA & 64 & 64 & 35 & 34 & 0.56 & PROCESSING PARAMETERS FOR \\
\hline PLA/ATBC & 20 & 43 & 11 & 10 & 0.16 & MELT PROCESSING OF NEAT PLA \\
\hline $\mathrm{PLA} / \mathrm{ATBC} / \mathrm{CS}$ & 22 & 38 & 22 & 21 & 0.35 & AND PLA WITH DIFFERENT \\
\hline PLA/LAPOL 108 & 60 & 60 & 32 & 31 & 0.51 & BIOPLASTICIZERS AND CHITOSAN \\
\hline PLA/LAPOL $108 / \mathrm{CS}$ & 40 & 56 & 33 & 33 & 0.55 & \\
\hline
\end{tabular}

Table 2

THERMAL PARAMETERS FOR NEAT PLA AND PLA WITH DIFFERENT PLASTICIZERS AND 1 WT.\% CS EVALUATED FROM DSC THERMOGRAMS

\begin{tabular}{|c|c|c|c|c|c|c|}
\hline Sample & $T_{g}\left({ }^{\circ} \mathrm{C}\right)$ & $\Delta \mathrm{H}_{\infty \mathrm{s}}\left(\mathrm{J} \mathrm{g}^{-1}\right)$ & $\mathrm{T}_{\mathrm{ec}}\left({ }^{\circ} \mathrm{C}\right)$ & $\Delta \mathrm{H}_{m}\left(\mathrm{~J} \mathrm{~g}^{-1}\right)$ & $\mathrm{T}_{\mathrm{m}}\left({ }^{\circ} \mathrm{C}\right)$ & $\mathrm{X}_{\mathrm{c}_{r} \mathrm{pL}, \mathrm{A}}(\%)$ \\
\hline PLA & 56.3 & 29.0 & 106.5 & 28.7 & $\begin{array}{l}155.7 \\
148.1\end{array}$ & 29.8 \\
\hline PLA/ATBC & 38.2 & 8.2 & 74.5 & 34.6 & 149.2 & 46.4 \\
\hline PLA/ATBC/CS & 39.9 & 5.4 & 72.8 & 24.0 & 149.8 & 38.8 \\
\hline PLA/LAPOL108 & 55.1 & - & - & 30.8 & $\begin{array}{l}150.2 \\
139.1\end{array}$ & 35.1 \\
\hline PLA/LAPOL108/CS & 51.0 & 6.1 & 86.5 & 22.2 & 153.1 & 25.6 \\
\hline
\end{tabular}

Brabender mixer (from $64 \mathrm{~N} \mathrm{~m}$ to $34 \mathrm{~N} \mathrm{~m}$ ). As the different plasticizing agents have been incorporated in the PLA matrix, a different behavior of the processing parameters was observed. Therefore, ATBC exhibits a low torque and melt viscosity than LAPOL 108. Incorporation of chitosan into melted PLA leads to increase of torque till $21 \mathrm{~N} \mathrm{~m}$ for PLA/ATBC/CS sample and to $33 \mathrm{~N}$ m for PLA/LAPOL 108/ CS sample respectively in comparison with plasticized PLA samples. However, these values are lower than that obtained in the case of PLA, showing that both plasticizers used led to the improvement of PLA biocomposites processability.

Fourier transform infrared (FT-IR) spectroscopy studies

Spectral features of neat PLA, plasticized PLA and plasticized PLA/CS samples are evidenced from FTIR spectra (fig. 1).

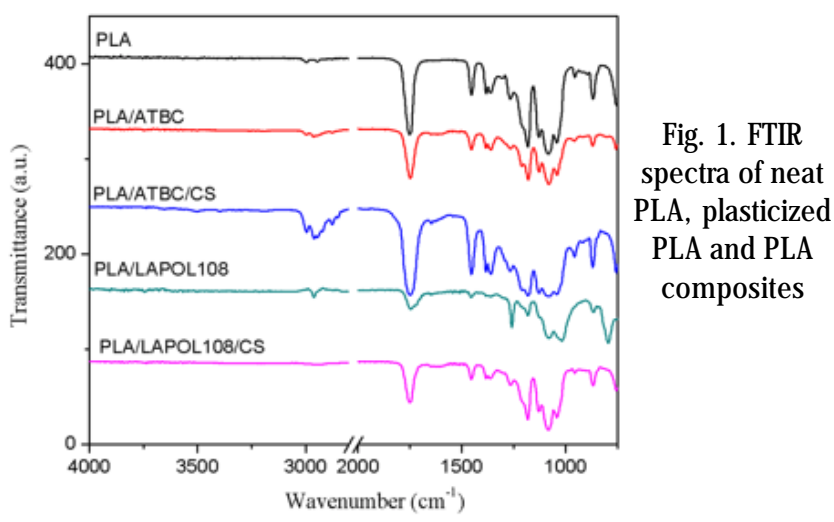

From figure 1 is observed that the PLA's spectrum is similar to those of PLA/ATBC and PLA/LAPOL 108 samples. The main characteristic bands of plasticized PLA films identified from figure 1 are detected at: $1749 \mathrm{~cm}^{-1}$ (attributed to the $C=0$ stretching vibration of PLA, evidenced for all samples), $754 \mathrm{~cm}^{-1}$ (crystalline phase of PLA), $868 \mathrm{~cm}^{-1}$ (amorphous PLA), $975 \mathrm{~cm}^{-1}$ (OH bond vibration of the carboxylic acid) $1041 \mathrm{~cm}^{-1}, 1084 \mathrm{~cm}^{-1}$ (stretching vibration of C-0- from O-C=0), $1128 \mathrm{~cm}^{-1}, 1182 \mathrm{~cm}^{-1}$ (stretching vibration of $\mathrm{CO}$ ), $1360 \mathrm{~cm}^{-1}$ (rocking vibration of $\mathrm{CH}$ from $\mathrm{CH}_{3}$; symmetrical deformation), $1454 \mathrm{~cm}^{-1}$ (vibration rocking $\mathrm{CH}$ in $\mathrm{CH}_{3}$; deformation asymmetric, $2999 \mathrm{~cm}^{-1}$ (stretching vibration of $\mathrm{CH}$ in $\mathrm{CH}_{3}$ ) [20-22]. With incorporation of chitosan into blends, in the case of PLA/ ATBC/CS sample it is observed an accentuated band at
2999-2848 $\mathrm{cm}^{-1}$ assigned to $\mathrm{CH}$ stretching and an increase in intensity of band at $1454 \mathrm{~cm}^{-1}$.

\section{Thermal properties}

DSC curves for neat PLA, plasticized PLA and PLA biocomposites are plotted in figure 2 and the thermal characteristics evaluated from the first heating run are summarized in table 2.

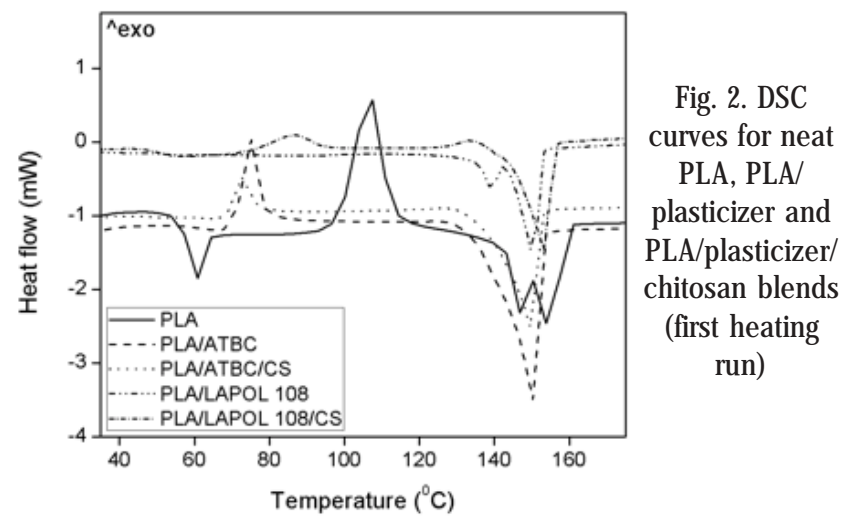

PLA samples with different plasticizers show a single $T$. In general, it is known that the $T$ depends on the mobility of the molecular chain segments. If the molecular chain segments are not restricted, their relaxing becomes easily, resulting in a decrease of T [11]. Indeed, ATBC plasticizer led to the increase of chain macromolecular mobility ( $T_{\text {}}$ $\left.=38.2{ }^{\circ} \mathrm{C}\right)$ which has an effect the promoting of crystallization ( $X=46.4 \%$ ) [18]. In the case of PLA/ LAPOL108 sample is observed a small decrease of $T$ than pure PLA, due to the high content of PLA from masterbatch. For PLA/LAPOL108/CS sample it is noticed a decrease in T compared with PLA/LAPOL108 sample, which means that the macromolecular chains segments encounter less resistance to movement caused by crystallization. The cold crystallization temperature $\left(T_{c c}\right)$ is shifted to lower temperatures with incorporation of plasticizer and chitosan into PLA matrix indicating a higher crystallization rate (table 2 . The cold-crystallization enthalpies of PLA blends decrease in respect with that of neat PLA, the plasticizers and CS hinder the crystallization. Thus, the addition of chitosan into plasticized PLA decreased the $X_{c}$ up to $~ 30 \%$ than the samples without CS. 


\begin{tabular}{|l|c|c|}
\hline Sample & WVTR $\left(\mathrm{g} \mathrm{m}^{-2}\right.$ day $\left.^{-1}\right)$ & OTR $\left(\mathrm{ml} \mathrm{m}^{-2}\right.$ day $\left.^{-1}\right)$ \\
\hline PLA & 15.9 & 263.4 \\
\hline PLA/ATBC & 42.5 & 455.1 \\
\hline PLA/ATBC/CS & 43.9 & 997.0 \\
\hline PLA/LAPOL108 & 30.8 & 45.5 \\
\hline PLA/LAPOL108/CS & 23.5 & 2401.6 \\
\hline
\end{tabular}
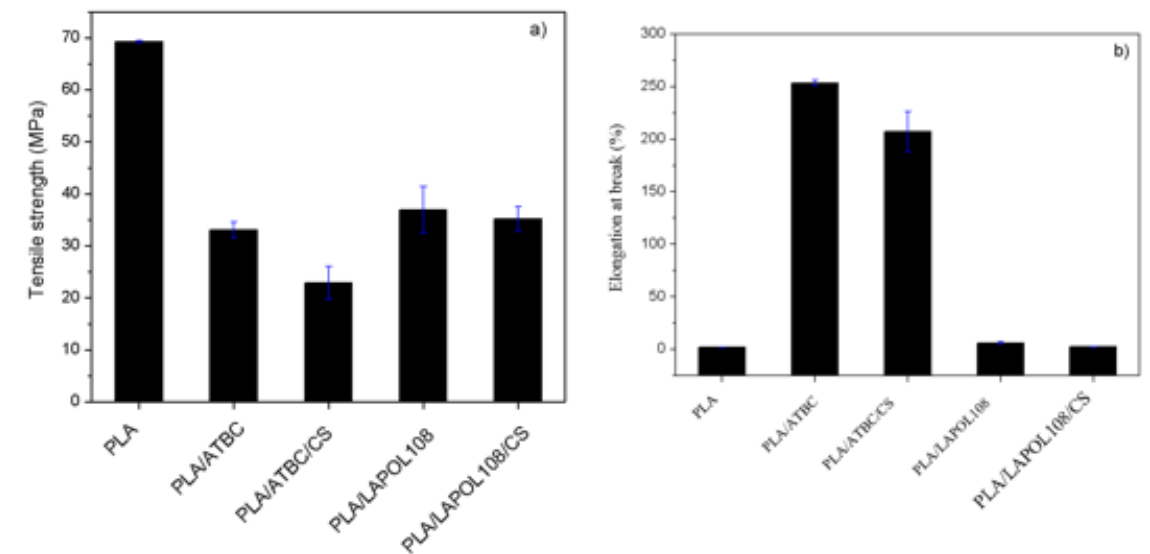

Fig. 3. Tensile properties for PLA, PLA/plasticizer and PLA/plasticizer/chitosan blends

a)Tensile strength at break, b) Elongation at break; c) Young Modulus

In generally the melting temperature $\left(T_{\text {}}\right)$ of samples does no change with addition of chitosan. PLA and PLA/ LAPOL 108 samples show a shoulder around the maximum temperature melting due to the melting of two different types of crystallites or to defects of some of present crystallites [22, 23].

\section{Tensile properties}

PLA has a high tensile strength ( $69.2 \pm 0.18 \mathrm{MPa}$ ) and Young modulus ( $4048 \pm 17 \mathrm{MPa}$ ) but because of its britleness the elongation at break is very low $(2.1 \pm 0.1 \%)$ (fig. 3).

The bioplasticizers acted differently on the tensile properties of PLA. The ATBC led, as expected, to a significant decrease in the tensile strength (33.07 \pm 1.56 $\mathrm{MPa}$ ) and elasticity modulus ( $23.16 \pm 1.21 \mathrm{MPa})$ of PLA, but the elongation at break significantly increased ( $253 \pm$ 2.7\%) [18]. Instead, the incorporation of LAPOL 108 conducted to a high modulus ( $3092 \pm 92 \mathrm{MPa}$ ) and a low elasticity at break ( $6 \pm 1.4 \%)$ than ATBC plasticizer. The small content of chitosan insignificantly decreased all tensile properties of PLA/LAPOL108 sample, because of the compatibilizer role of LAPOL 108 for PLA blends, while for PLA/ATBC/CS sample this decrease is more accentuated. This is due to the thermodynamic immiscibility between PLA and chitosan, effect also reported by other authors [16, 17, 24]. However, based ontensile properties showed in figure 3 it can appreciated that the PLA/ATBC/CS blend is adequate for design of flexible food packaging processed by extrusion technology, while the PLA/LAPOL108/CS sample could be recommended for obtaining of rigid food packaging by injection-moulding.

\section{Barrier properties}

Water vapor transmission rate (WVTR) and oxygen transmission rate (OTR) are presented in table 3.

For conventional food packaging (LDPE/LLDPE) have been reported following barrier properties: WVTR in the range of $15-25 \mathrm{~g} \mathrm{~m}^{-2}$ day $^{-1}$ ( $25 \mu \mathrm{m}$ film, test conditions 38 ${ }^{\circ} \mathrm{C}, 90 \%$ relative humidity) and OTR $7000-8000 \mathrm{~mL} \mathrm{~m}^{-2}$ day $^{-1}$ (test conditions $25^{\circ} \mathrm{C}, 50 \%$ relative humidity, 1 atmosphere) [25]. The PLA samples showed the barrier properties values below those of commercial polymers -

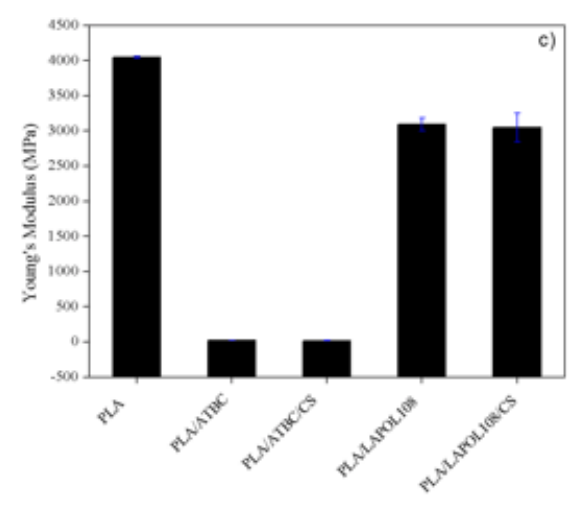

Table 3

BARRIER PROPERTIES OF SAMPLES

table 3. Incorporation of CS into plasticized PLA led to a significant increase of OTR values, according to the results reported in literature [26]. It is known that the barrier properties of polymer mixtures are determined by the characteristics of their crystallinity [27]. A high degree of crystallinity refers to the improving of the barrier properties of films mainly because the water diffuses into the amorphous regions (crystals are considered to be waterproof). Indeed, the PLA/ATBC and PLA/LAPOL108 blends showed a higher degree of crystallinity compared with the same samples containing chitosan (table 2), so their barrier properties both at water vapor and oxygen are improved. Among two bioplasticizers used, LAPOL 108 is more efficient. PLA/LAPOL108/CS registered a small decrease of WVTR compared to the sample without chitosan, probably to the poor dispersion of CS into PLA matrix.

\section{Overall migration}

In table 4 are reported the overall migrations of some compounds from studied samples into simulants.

The PLA/ATBC sample shows an overall migration in $3 \%$ acetic acid below the limit of overall migration of 10 $\mathrm{mg} \mathrm{dm}{ }^{-2}$ but the migration increased with incorporation of chitosan, indicating the release of chitosan from the material (table 4). Also, in contact with 50\% ethanol, for 10 days at temperature of $40^{\circ} \mathrm{C}$, the migration rates for PLA/ATBC samples were impossible to measure, since the residue from the test was at a liquid state. Based on the amount of migrant, it is likelythere has been a extraction of the ATBC plasticizer into the food simulant during exposure [18]. This behavior of PLA-based ATBC and CS can be also explained by the $T$ values very closed to the test temperature recorded by these samples $\left(\sim 39^{\circ} \mathrm{C}\right.$, as observed in table 2).

In the case of PLA/LAPOL 108 and PLA/LAPOL108/CS samples, the overall migration in both simulants is below that the overall migration limit of $10 \mathrm{mg} \mathrm{dm}^{-2}$, however a considerably higher migration for the material containing chitosan compared to the one without chitosan was encountered. For these materials, the migration occured at a temperature below to the $T$ values $\left(51-55^{\circ} \mathrm{C}\right.$ ) and the structural changes in molecular chains did not take place. In both simulants was observed a color change for the 


\begin{tabular}{|l|c|c|c|}
\hline \multirow{2}{*}{ Sample } & \multicolumn{2}{|c|}{ Overall migration $\left(\mathrm{mg} \mathrm{dm}^{-2}\right.$ ) } \\
\cline { 2 - 3 } & $\begin{array}{c}3 \% \text { acetic acid (w/v) } \\
\text { (Simulant B) }\end{array}$ & $\begin{array}{c}50 \% \text { ethanol } \\
\text { (v/v) } \\
\text { (Simulant D1) }\end{array}$ & $\begin{array}{c}\text { Required by } \\
\text { Regulation (EU) No. 10/2011 }\end{array}$ \\
\hline PLA/ATBC & $0.9 \pm 0.1$ & $\sim 400$ & $<10 \mathrm{mg} \mathrm{dm}^{-2}$ \\
\hline PLA/ATBC/CS & $18.3 \pm 0.4$ & $\sim 400$ & \\
\hline PLA/LAPOL108 & $0.4 \pm 0.3$ & $6.0 \pm 0.5$ & \\
\hline PLA/LAPOL108/CS & $4.8 \pm 0.1$ & $8.0 \pm 2.8$ & \\
\hline
\end{tabular}

Table 4

OVERALL MIGRATION VALUES FOR PLASTICIZED PLA AND PLA BIOCOMPOSITES INTO FOOD SIMULANTS FOR 10 DAYS AT $40^{\circ} \mathrm{C}$

\begin{tabular}{|l|c|c|c|}
\hline Sample & $\begin{array}{c}\text { A. brasiliensis } \\
\text { ATCC 16404 }\end{array}$ & $\begin{array}{c}\text { F. graminearum } \\
\text { G87 }\end{array}$ & $\begin{array}{c}\text { P. corylophilum } \\
\text { CBMF1 }\end{array}$ \\
\hline PLA & 100 & 100 & 100 \\
\hline PLA/ATBC & $99 \pm 0.45$ & $84.16 \pm 12.93$ & $99.5 \pm 0.79$ \\
\hline PLA/ATBC/CS & $99.9 \pm 0.28$ & $95.58 \pm 7.80$ & $99.58 \pm 0.66$ \\
\hline PLA/LAPOL108 & $96.08 \pm 7.56$ & $96.66 \pm 7.78$ & 100 \\
\hline PLA/LAPOL108/CS & $96.25 \pm 7.72$ & $94.91 \pm 5.14$ & $99.83 \pm 0.38$ \\
\hline
\end{tabular}

Table 5

THE INHIBITION RATE (\%) OF NEAT PLA, PLA/PLASTICIZER AND PLA/PLASTICIZER/CHITOSAN BLENDS AGAINST THREE FOOD DEGRADATION FUNGI
PLA/LAPOL 108 and PLA/LAPOL 108/CS samples after 10 days contact. In addition, the PLA/LAPOL 108/CS sample became very brittle after contact with ethanol simulant. Therefore, based on the behavior of investigated samples at food simulants, the PLA/ATBC material can be recommended for fatty and acidic food, while PLA/LAPOL 108 and PLA/LAPOL108/CS samples could be recommended for both fatty and acidic food and also for aqueous, alcoholic and milky food.

\section{Antifungal properties}

The results concerning antifungal properties of PLA, plasticized PLA and PLA biocomposites were expressed as a percentage by visual approximation of the material surface (the one in contact with the Aspergillus brasiliensis ATCC 16404, Fusarium graminearum G87 and Penicillium corylophilum CBMF1 fungi), on which the mycelia of the fungus wasn't present (inhibition rate (IR)) (table 5).

From Table 5 it is observed that the antifungal activity of PLA could be due to the residual lactic acid monomer in commercial PLA [18, 28] and due to low permeability both to water vapors and oxygen as it is presented in the table 3 , as long as it's well known that fungi are aerobic microorganisms.

The ATBC, LAPOL 108 plasticizers and chitosan incorporated into PLA matrix (except PLA/LAPOL 108 sample) conducted to significant increasing values of permeability. This increase is strongly accentuated by the addition of chitosan especially for OTR test. These changes in material barrier properties led to an increase of the tested fungi development, compared to neat PLA. However, the inhibition rates against Aspergillus brasiliensis, Fusarium graminearum G87 and Penicilium corylophilum CBMF1 fungi are still high ( $>80 \%$ ) this fact can be due to antifungal effect of chitosan and PLA and thus, all samples assured a good antifungal activity against the tested degradation fungi.

\section{Conclusions}

A comparative analysis of the two different bioplasticizers on the mechanical, thermal and antifungal properties of PLA based biocomposites containing 1\% chitosan was conducted in this study.
The obtained results revealed that the ATBC led to a good melt procesability, oxygen barrier and increased crystallinity compared with LAPOL 108 bioplasticizer.

It can appreciated that the PLA/ATBC/CS biocomposite could be considered for flexible food packaging designing, for fatty/acidic food products, while the PLA/LAPOL108/ CS biocomposite could be recommended for rigid food packaging, for fatty and acidic food and also for aqueous, alcoholic and milky food products.

All samples showed antifungal properties against Aspergillus brasiliensis ATCC 16404, Fusarium graminearum G87 and Penicillium corylophilum CBMF1 fungi being promising materials to be used as food packaging materials.

Acknowledgements: The research leading to these results has received funding from the Romanian EEA Research Programme operated by MEN under the EEA Financial Mechanism 2009-2014 and Project ACTIBIOSAFE, under the Contract No 1SEE/30.06.2014.

\section{References}

1. SANCHEZ-GARCIA, M.D., LOPEZ-RUBIO, A., LAGARON, J.M., Trends Food. Sci. Tech. 21, 2010, p. 528.

2. LOPEZ O.V., CASTILLO L.A., GARCIA M.A., VILLAR M.A., BARBOSA S.E., Food Hydrocoll. 43, 2015, p. 18.

3. PETERSEN, K., NIELSEN, P. AND OLSEN, M., Starch 53, 2001, p. 356. 4. TRI, P.N., DOMENEK, S., GUINAULT, A., SOLLOGOUB, C., J. Appl. Polym. Sci. 129, no. 6, 2013, p. 3355.

5. GU, S.Y., ZHANG, K., REN, J., ZHAN, H., Carbohydr. Polym. 74, 2008, p. 79.

6. SIN, L.T., RAHMAT, A.R., RAHMAN, W.A.W.A., Polylactic Acid. PLA Biopolymers Technology and Applications, $1^{\text {st }}$ Edition, Elsevier Inc., PDL HANDBOOK SERIES, Ebnesajjad, S., 2013, p. 177.

7. HASSOUNA, F., RAQUEZ, J.M., ADDIEGO, F., DUBOIS, P., T. ONIAZZO, V., RUCH, D., Eur. Polym. J., 47, 2011, p. 2134.

8. ABDELWAHAB, M.A., FLYNN, A., CHIOU, B.S., IMAM, S., ORTS, W., CHIELLINI, E., Polym. Degrad. Stab. 97, no. 9, 2012, p. 1822.

9. MEKONNEN, T., MUSSONE, P., KHALIL, H., BRESSLER, D., J. Mater. Chem. A, 2013, 1, p. 13379.

10. RAPA ,M., DARIE NITA, R.N., VASILE, C., Mat. Plast. 54, no. 1, 2017, p. 73.

11. DARIE NITA, R.N., VASILE, C., IRIMIA, A., LIPSA, R., RAPA, M., J. Appl. Polym. Sci., 133, no. 13, 2016, p. 1. 
12. ZHAI, W., KO, Y., ZHU, W., WONG, A., PARK, C.B., Int. J. Mol. Sci. 10, 2009, p. 5381.

13. DUTTA, P.K., TRIPATHI, S., MEHROTRA, G.K., DUTTA, J., Food. Chem. 114, no. 4, 2009, p. 1173.

14. LAMBERTUS, A.M., DEN BROEK, V., KNOOP, R.J.I., KAPPEN, F.H.J ., BOERIU, C.G., Carbohyd. Polym. 116, 2015, p. 237.

15. WANG, H., ZHANG, R., ZHANG, H., JIANG, S., LIU, H., SUA, M., JIANG, S., Carbohydr. Polym. 127, 2015, p. 64.

16. QUIROZ-CASTILLO, J.M., RODRIGUEZ-FELIX, D.E., GRIJ ALVAMONTEVERDE, H., DEL CASTILLO-CASTRO, T., PLASCENCIAJATOMEA, M., RODRIGUEZ-FELIX, F., HERRERA-FRANCO, P.J ., Carbohydr. Polym. 101, 2014, p. 1094.

17. REESHA, K.V., PANDA, S.K., BINDU, J., VARGHESE, T.O., Int. J. Biol. Macromol. 79, 2015 , p. 934.

18. RAPA, M., MITELUT, A.C., TANASE, E.E., GROSU, E., POPESCU, P., POPA, M.E., ROSNES, J.T., SIVERTSVIK, M., DARIE-NITA, R.N., VASILE, C., Composites Part B 102, 2016, p. 112.

19.*** Union Guidelines on Regulation (EU) N 10/2011 On plastic materials and articles intended to come into contact with food. Official Journal of European Communities (2011).
20. GONZALEZ, A., ALVAREZ IGARZABAL, C.I., Food Hydrocolloid. 33, 2013, p. 289.

21. WANG, N., ZHANG, X., MA, X., FANG, J., Polym. Degrad. Stabil. 93, 2008, p. 1044.

22. ZEMBOUAI, I., KACl, M., BRUZAUD, S., BENHAMIDA, A., CORRE, Y.M., GROHENS, Y.A., Polym Test. 32, 2013, p. 842.

23. BONILLA, J., FORTUNATI, E., VARGAS, M., CHIRALT, A., KENNY, J.M., J. Food Eng. 119, 2013, p. 236.

24. CORRELO, V.M., BOESEL, L.F., BHATTACHARYA, M., MANO, J.F., NEVES, N.M., REIS, R.L., Mat. Sci. Eng. A-Struct. 403, 2005, p. 57.

25. EMBLEM, A. Plastics properties for packaging materials, Emblem A. and Emblem H., (C) Woodhead Publishing Limited, 2012, p. 287.

26. FERNANDEZ-SAIZ, P., OCIO, M.J., LAGARON, J .M., Carbohyd. Polym. 80, 2010, p. 874.

27. ANSARI, S., FATMA, T., IJIRSET 3, no. 2, 2014, p. 9494.

28. VASILE, C., RAPA, M., STEFAN, M., STAN, M., MACAVEI, S., DARIENITA, R.N., BARBU-TUDORAN, L., VODNAR, D.C., POPA, E.E., STEFAN, R., BORODI, G., BREBU, M., eXPRESS Polym Lett. 11, 2017, p. 531.

Manuscript received: 13.07 .2017 